\title{
Chemical Loss of Ozone in the Arctic Polar Vortex in the Winter of 1991-1992
}

\author{
R. J. Salawitch, S. C. Wofsy, E. W. Gottlieb, L. R. Lait, \\ P. A. Newman, M. R. Schoeberl, M. Loewenstein, J. R. Podolske, \\ S. E. Strahan, M. H. Proffitt, C. R. Webster, R. D. May, \\ D. W. Fahey, D. Baumgardner, J. E. Dye, J. C. Wilson, \\ K. K. Kelly, J. W. Elkins, K. R. Chan, J. G. Anderson
}

In situ measurements of chlorine monoxide, bromine monoxide, and ozone are extrapolated globally, with the use of meteorological tracers, to infer the loss rates for ozone in the Arctic lower stratosphere during the Airborne Arctic Stratospheric Expedition II (AASE II) in the winter of 1991-1992. The analysis indicates removal of 15 to 20 percent of ambient ozone because of elevated concentrations of chlorine monoxide and bromine monoxide. Observations during AASE II define rates of removal of chlorine monoxide attributable to reaction with nitrogen dioxide (produced by photolysis of nitric acid) and to production of hydrochloric acid. Ozone loss ceased in March as concentrations of chlorine monoxide declined. Ozone losses could approach 50 percent if regeneration of nitrogen dioxide were inhibited by irreversible removal of nitrogen oxides (denitrification), as presently observed in the Antarctic, or without denitrification if inorganic chlorine concentrations were to double.

Loss rates for $\mathrm{O}_{3}$ were estimated for the lower stratosphere during AASE II in 1991-1992. We computed distributions of reactive chlorine $\left(\mathrm{Cl}^{*} \equiv[\mathrm{ClO}]+2 \times\right.$ $\left.\left[(\mathrm{ClO})_{2}\right]\right)$ and bromine $\left(\mathrm{Br}^{*} \equiv[\mathrm{BrO}]+\right.$ $[\mathrm{BrCl}]$ ) (where brackets denote concentration) along the flight track of the ER-2 airplane by assimilating in situ observations of $\mathrm{ClO}$ and $\mathrm{BrO}$ with a simple

R. J. Salawitch, S. C. Wotsy, E. W. Gottlieb, Division of Applied Sciences and Department of Earth and Planetary Sciences, Harvard University, Cambridge, MA 02138.

L. R. Lait, P. A. Newman, M. R. Schoeberl, S. E Strahan, National Aeronautics and Space Administration (NASA) Goddard Space Flight Center, Greenbelt. MD 20771.

M. Loewenstein J R Podolske, K R Chan, NASA Ames Research Center. Moffett Field, CA 94035

M. H. Proffitt, D. W. Fahey, K. K. Kelly, National Oceanic and Atmospheric Administration (NOAA) Aeronomy Laboratory, Boulder, CO 80303

C. R. Webster and R. D. May, Jet Propulsion Labora tory, Pasadena, CA 91109

D. Baumgardner and J. E. Dye, National Center for Atmospheric Research, Boulder, $\mathrm{CO} 80307$.

J. C. Wilson, Department of Engineering, University of Denver, Denver, CO 80208

J. W. Elkins, NOAA Climate Monitoring and Diagnostics Laboratory, Boulder, CO 80303.

J. G. Anderson, Departments of Earth and Planetary Sciences and Chemistry. Harvard University, Cam bridge, MA 02138 model. Relations between potential vorticity (PV) and potential temperature $(\Theta)$, meteorological tracers $(1,2)$, and $\mathrm{Cl}^{*}$ and $\mathrm{Br}^{*}$ were developed to compute $\mathrm{O}_{3}$ loss rates for the north polar region, accounting for the influence of insolation, temperature, and pressure as air circulates around the polar vortex $(3,4)$. Seasonal changes observed for $\mathrm{ClO}(5), \mathrm{NO}(6)$, $\mathrm{HCl}$ (7), and $\mathrm{O}_{3}(8)$ were investigated with the use of a photochemical model constrained by meteorological observations (9) and measured surface areas for sulfate aerosol $(10)$; factors regulating chemical removal of $\mathrm{O}_{3}$ in the Arctic were examined with this model.

Reactions on the surfaces of polar stratospheric clouds (PSCs) (11), which are composed of condensed phases of $\mathrm{H}_{2} \mathrm{O}$ and $\mathrm{HNO}_{3}(12)$, catalyze the rapid conversion of $\mathrm{HCl}$ and $\mathrm{ClNO}_{3}$ to labile species of inorganic chlorine in the polar vortex during winter $(13,14)$. Three catalytic cycles involving halogens account for $-95 \%$ of photochemical loss of $\mathrm{O}_{3}$ in the vortex.

1) The self-reaction of $\mathrm{ClO}$ forming its dimer, $(\mathrm{ClO})_{2}$, followed by photolysis

SCIENCE • VOL. 261 • 27 AUGUST 1993
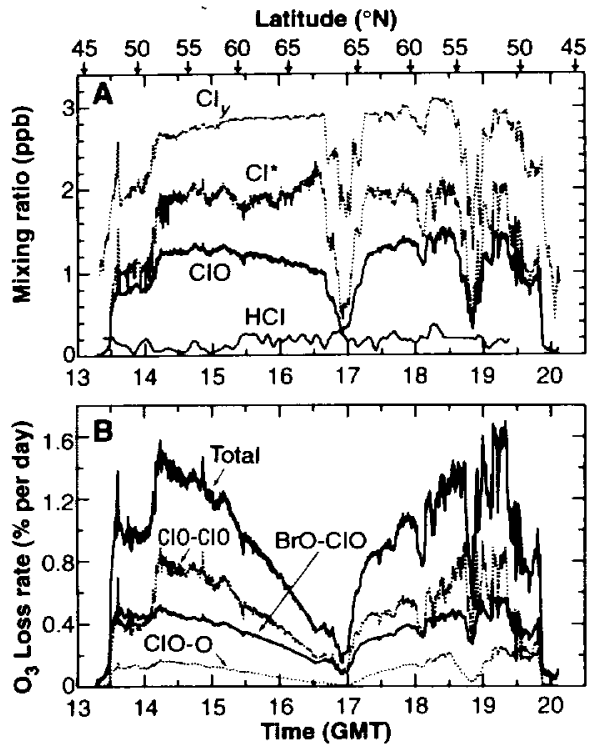

Fig. 1. Observations and reconstructions for 20 January 1992. (A) Observed mixing ratios of $\mathrm{ClO}$ and $\mathrm{HCl}$, inferred mixing ratios for $\mathrm{Cl}^{*}$ and $\mathrm{Cl}_{y^{\prime}}$ and (B) the 24-hour mean loss rates for ozone, computed using $\mathrm{Eq} .4$ and $\mathrm{Cl}^{*}$ shown in (A). The total recombination rate and contributions from the $\mathrm{ClO}-\mathrm{ClO}, \mathrm{BrO}-\mathrm{ClO}$, and $\mathrm{ClO}-\mathrm{O}$ catalytic cycles (reactions 1,2 , and 3 ) are shown. All measurements taken along the ER-2 flight track, plotted against universal time (GMT). Corresponding latitudes are indicated at the top of the figure

$$
\begin{aligned}
\mathrm{ClO}+\mathrm{ClO}+\mathrm{M} & \rightarrow(\mathrm{ClO})_{2}+\mathrm{M}(1) \\
(\mathrm{ClO})_{2}+h v & \rightarrow \mathrm{ClOO}+\mathrm{Cl} \\
\mathrm{ClOO} & \rightarrow \mathrm{Cl}+\mathrm{O}_{2} \\
2\left(\mathrm{Cl}+\mathrm{O}_{3}\right. & \left.\rightarrow \mathrm{ClO}+\mathrm{O}_{2}\right) \\
\mathrm{Net}: 2 \mathrm{O}_{3} & \rightarrow 3 \mathrm{O}_{2}
\end{aligned}
$$

catalyzes the recombination of two $\mathrm{O}_{3}$ molecules with the use of one photon (with energy $h v$ ) (15). Thermal decomposition of (ClO), short-circuits this cycle, regenerating $\mathrm{ClO}$ without producing $\mathrm{Cl}$ atoms or recombining $\mathrm{O}_{3}$.

2) The reaction of $\mathrm{BrO}$ and $\mathrm{ClO}$ and the photolysis of $\mathrm{BrCl}$

$$
\begin{aligned}
\mathrm{BrO}+\mathrm{ClO} & \rightarrow \mathrm{Cl}+\mathrm{Br}+\mathrm{O}_{2} \\
& \rightarrow \mathrm{Br}+\mathrm{OClO} \\
& \rightarrow \mathrm{BrCl}+\mathrm{O}_{2} \\
\mathrm{BrCl}+h v & \rightarrow \mathrm{Br}+\mathrm{Cl} \\
\mathrm{Br}+\mathrm{O}_{3} & \rightarrow \mathrm{BrO}+\mathrm{O}_{2} \\
\mathrm{Cl}+\mathrm{O}_{3} & \rightarrow \mathrm{ClO}+\mathrm{O}_{2}
\end{aligned}
$$

Net $(2 \mathrm{a}, 2 \mathrm{c}): 2 \mathrm{O}_{3} \rightarrow 3 \mathrm{O}_{2}$

also catalyzes recombination of $\mathrm{O}_{3}$ (13). Photolysis of $\mathrm{OClO}$ produces $\mathrm{O}$ atoms; therefore, reaction $2 \mathrm{~b}$ does not destroy $\mathrm{O}_{3}$ (16).

3) The reaction sequence 


\section{Chemical Loss of Ozone in the Arctic Polar Vortex in the Winter of 1991-1992}

R. J. Salawitch, S. C. Wofsy, E. W. Gottlieb, L. R. Lait, P. A. Newman, M. R. Schoeberl, M. Loewenstein, J. R. Podolske, S. E. Strahan, M. H. Proffitt, C. R. Webster, R. D. May, D. W. Fahey, D. Baumgardner, J. E. Dye, J. C. Wilson, K. K. Kelly, J. W. Elkins, K. R. Chan, and J. G. Anderson 


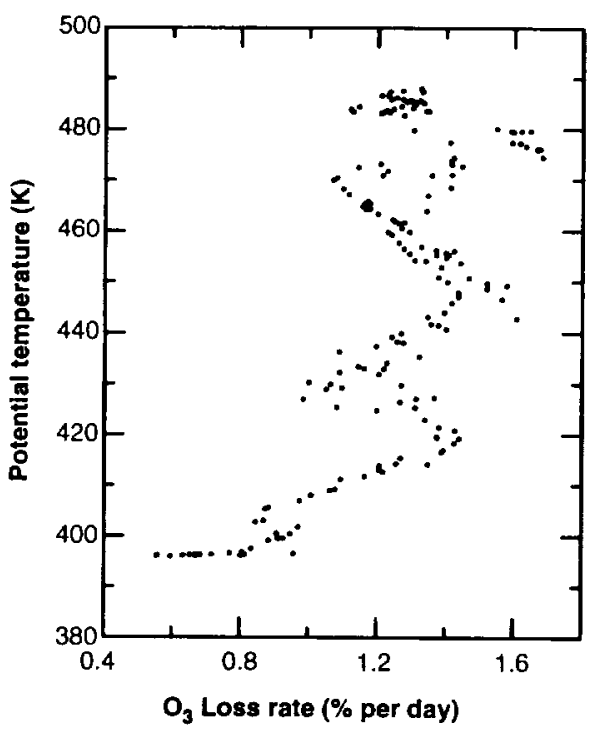

Fig. 2. The 24-hour mean loss rates for $\mathrm{O}_{3}$ plotted against potential temperature $\Theta$, for observations taken on 20 January 1992 during the descent and ascent in sunlight (solar zenith angle $<80^{\circ}$ ) at $52^{\circ} \mathrm{N}$. The altitudes 20,16 , and $15 \mathrm{~km}$ correspond approximately to $\Theta=500$. 420 , and $400 \mathrm{~K}$, respectively.

$$
\begin{aligned}
\mathrm{ClO}+\mathrm{O} & \rightarrow \mathrm{Cl}+\mathrm{O}_{2} \\
\mathrm{Cl}+\mathrm{O}_{3} & \rightarrow \mathrm{ClO}+\mathrm{O}_{2}
\end{aligned}
$$

Net: $\mathrm{O}+\mathrm{O}_{3} \rightarrow 2 \mathrm{O}_{2}$

represents a minor loss of $\mathrm{O}_{3}$, with rates accelerating in spring when the concentration of $\mathrm{O}$ atoms increases.

Hydrolysis of $\mathrm{N}_{2} \mathrm{O}_{5}$ on sulfate aerosols efficiently converts $\mathrm{NO}_{x}\left(\mathrm{NO}+\mathrm{NO}_{2}\right)$ to $\mathrm{HNO}_{3}$, which is very stable at low sun angles $(6,17)$. Catalytic cycles involving $\mathrm{NO}_{x}$, normally important at mid-latitudes, are negligible in the winter polar stratosphere (18). The catalytic cycle involving reaction of $\mathrm{ClO}$ with $\mathrm{HO}_{2}$ represents less than $5 \%$ of the total loss of $\mathrm{O}_{3}$ lon the basis of calculated values for $\mathrm{HO}_{2}$, corroborated by column measurements of $\mathrm{HOCl}$ (19) $\mid$ and is therefore not considered here.

The photochemical loss rate of ozone is

$$
\begin{aligned}
\frac{d\left[\mathrm{O}_{3}\right]}{d \mathrm{t}}= & -2\left\{k_{\mathrm{ClO}}+\mathrm{ClO} R[\mathrm{M}][\mathrm{ClO}]^{2}\right. \\
+\left(k_{\mathrm{ClO}}\right. & \left.+\mathrm{BrO}_{(\mathrm{a})}+k_{\mathrm{ClO}+\mathrm{BrO}(\mathrm{c})}\right)[\mathrm{BrO}][\mathrm{ClO}] \\
& \left.+k_{\mathrm{O}+\mathrm{ClO}}[\mathrm{O}][\mathrm{ClO}]\right\}
\end{aligned}
$$

where $k$ is the rate coefficient for the specified reaction, $M$ denotes an air molecule, and $R$ is

$$
\frac{J_{(\mathrm{ClO})_{2}}\left[(\mathrm{ClO})_{2}\right]}{J_{(\mathrm{ClO})_{2}}\left[(\mathrm{ClO})_{2}\right]+k_{\left(\mathrm{ClO}_{2}+\mathrm{M}\right.}[\mathrm{M}]\left[(\mathrm{ClO})_{2}\right]}
$$

the fraction of $(\mathrm{ClO})$, that photolyzes, where $J$ is the photolysis frequency for the specified reaction. Removal rates attributable to reaction 1 decline at temperatures above $220 \mathrm{~K}$, where $R \rightarrow O(20)$. Loss of $\mathrm{O}_{3}$ requires sunlight to photolyze $(\mathrm{ClO})_{2}, \mathrm{BrCl}$ (the

Fig. 3. Observed mixing ratios for $\mathrm{ClO}(\boldsymbol{)})$ and $\mathrm{N}_{2} \mathrm{O}$ (dashed line) and inferred mixing ratios for $\mathrm{Cl}$ * $(\square)$ and $\mathrm{Cl}_{y}(-)$ on the isentropic surface defined by $\Theta=470 \pm 10$ $\mathrm{K}$, plotted against potential vorticity (PV). Data were averaged in intervals of PV equal to $5 \times 10^{-7}$ $\mathrm{K} \mathrm{m}^{2} \mathrm{~kg}^{-1} \mathrm{~s}^{-1}$. The edge of the polar vortex was located at $P V=$ $2.1 \times 10^{-5}$ with a transition region between $2.3 \times 10^{-5}$ and $3 \times$

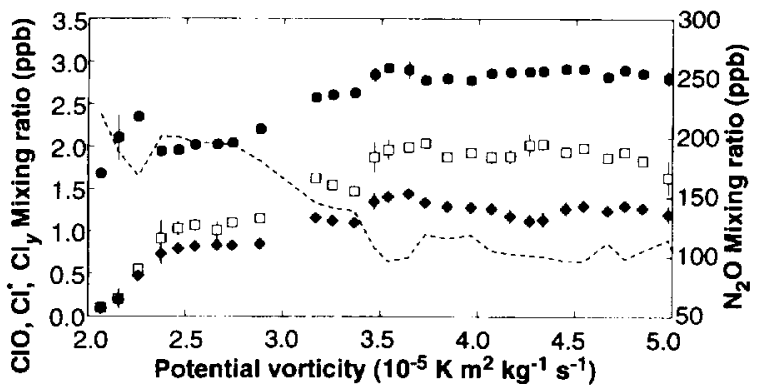
$10^{-5} \mathrm{~K} \mathrm{~m}^{2} \mathrm{~kg}^{-1} \mathrm{~s}^{-1}$. The interior of the vortex had uniform concentrations of $\mathrm{Cl}_{\mathrm{y}} \approx 2.8 \mathrm{ppbv}$ and $\mathrm{Cl}^{*} / \mathrm{Cl}_{y} \approx 0.75$. Vertical bars denote standard deviation (smaller than the symbol in many bins)

nighttime reservoir for $\mathrm{BrO}$ ), and $\mathrm{O}_{3}$ (to generate $\mathrm{O}$ atoms).

Equation 4 allows us to compute instantaneous rates for $\mathrm{O}_{3}$ loss along a flight track directly from measured radicals $(5,21)$, apart from $R$ and $|O|$, which are calculated with Eqs. 5 and 7 below. To determine global loss rates of $\mathrm{O}_{3}$, we must infer radical concentrations throughout the polar vortex from observations along the flight track, and the loss rate must be integrated over 24 hours (3).

The diurnal variations of $\mathrm{ClO}, \mathrm{BrO}$, and $\mathrm{O}$ are governed by

$$
\begin{aligned}
& \frac{d[\mathrm{ClO}]}{d t}=2\left\{J_{(\mathrm{ClO})_{2}}+k_{(\mathrm{ClO})_{2}+\mathrm{M}}[\mathrm{M}]\right\}(\mathrm{ClO})_{2} \\
& -2 k_{\mathrm{ClO}+\mathrm{ClO}+\mathrm{M}}\left[\mathrm{M} \mid[\mathrm{ClO}]^{2}\right. \\
& \frac{d[\mathrm{BrO}]}{d t}=J_{\mathrm{BrCl}}[\mathrm{BrCl}] \\
& -k_{\mathrm{ClO}+\mathrm{BrO}(\mathrm{c})}[\mathrm{BrO}][\mathrm{ClO}] \\
& \frac{d[\mathrm{O}]}{d t}=J_{\mathrm{O}_{3}}\left[\mathrm{O}_{3}\right]-k_{\mathrm{O}+\mathrm{O}_{2}+\mathrm{M}}[\mathrm{O}]\left[\mathrm{O}_{2}\right][\mathrm{M}]
\end{aligned}
$$

Equation 5 balances production and loss of $(\mathrm{ClO})_{2}$, Eq. 6 balances production and photolysis of $\mathrm{BrCl}$, and $\mathrm{Eq} .7$ balances photolysis of $\mathrm{O}_{3}$ with recombination of $\mathrm{O}$ and $\mathrm{O}_{2}$; each process has a relaxation time shorter than $1000 \mathrm{~s}$. We determined the concentration of reactive chlorine corresponding to each measurement of $\mathrm{ClO}$ by matching observations to diurnal calculations with Eq. 5. Concentrations of $\mathrm{BrO}$ were about twice as high inside the vortex than outside, with little change during the winter; hence, a fixed relation was adopted between $\mathrm{Br}^{*}$ and $\Theta(22)$.

Concentrations of $\mathrm{ClO}$ began to increase dramatically in late December after temperatures over Asia had cooled to the threshold for PSCs $(5,9)$. Concentrations of $\mathrm{ClO}$ peaked in late January and then declined slowly in February and March. On 20 January 1992, the ER-2 aircraft departed Bangor, Maine $\left(44^{\circ} 47^{\prime} \mathrm{N}, 68^{\circ} 47^{\prime} \mathrm{W}\right)$, at 1300 GMT, flew north at $\sim 18-\mathrm{km}$ altitude $(\Theta=460 \mathrm{~K})$, and turned south to return at $\sim 19 \mathrm{~km}(\Theta=490 \mathrm{~K})$, with brief descents to $15 \mathrm{~km}$ at $65^{\circ}$ and $52^{\circ} \mathrm{N}$. Figure $1 \mathrm{~A}$ shows data for $\mathrm{ClO}$ and $\mathrm{HCl}$ and inferred values of $\mathrm{Cl}^{*}$ and total inorganic chlorine, $\mathrm{Cl}_{y} \mid \mathrm{com}$ puted from observations of $\mathrm{N}_{2} \mathrm{O}$ and organochlorine gases (23)]. A steep decline in $\mathrm{N}, \mathrm{O}$ and an increase in $\mathrm{ClO}$ were observed just north of Bangor (Fig. 1A) at the edge of the polar vortex $\left(\mathrm{PV} \approx 2.1 \times 10^{-5} \mathrm{~K} \mathrm{~m}^{2}\right.$ $\mathrm{kg}^{-1} \mathrm{~s}^{-1}$ ). Mixing ratios for $\mathrm{ClO}$ rose to 0.8 parts per billion by volume (ppbv) ( $1 \mathrm{ppbv}$ $=10^{-9}$ mole fraction in air) near the vortex edge, increasing to 1.2 to $1.4 \mathrm{ppbv}$ further inside; less than $15 \%$ of $\mathrm{Cl}_{y}$ was converted to $\mathrm{Cl}^{*}$ outside the vortex, $60 \%$ near the edge, and 75 to $85 \%$ in the interior (24). Figure 1B shows loss rates of ozone along the flight track, computed by integrating Eq. 4 over 24 hours. Removal rates exceeded $1.4 \%$ per day: $50 \%$ attributed to reaction $1,35 \%$ to 2 , and $15 \%$ to 3 .

Ozone loss rates in the polar vortex (Fig. 2) were uniform for $420<\Theta<500 \mathrm{~K}$ (16 to $20 \mathrm{~km}$ ), declining at lower $\Theta$. The mixing ratios of $\mathrm{ClO}, \mathrm{Cl}^{*}, \mathrm{Cl}_{\gamma}$, and $\mathrm{N}_{2} \mathrm{O}$ versus $P V$ for $\Theta=470 \pm 10 \mathrm{~K}$ are shown in Fig. 3. Monotonic increases of the $\mathrm{Cl}^{*}$ value on an isentropic (constant $\Theta$ ) surface were derived for 8 of the 10 flights in the vortex; similar values for $\mathrm{Cl}^{*}$ were observed for a given PV on flights a few days apart. These results imply a homogeneous distribution for $\mathrm{Cl}^{*}$ in the polar vortex, extending over more than $4 \mathrm{~km}$ in the vertical and as far north as $70^{\circ} \mathrm{N}$. Values of $\mathrm{Cl}^{*}$ versus PV were similar in 1989 and 1992 (3).

We computed distributions of $\mathrm{Cl}^{*}$ and daily loss rates for $\mathrm{O}_{3}$ throughout the vortex using global meteorological fields for PV and the observed relation between $\mathrm{Cl}^{*}$ and PV (Fig. 4). Regions with elevated $\mathrm{Cl}^{*}$ were exposed to sunlight in lobes of the vortex that extended to $45^{\circ} \mathrm{N}$, one of which was sampled by the ER-2. The mean ozone loss rate for the vortex region (PV > $2.1 \times$ $10^{-5} \mathrm{~K} \mathrm{~m}^{2} \mathrm{~kg}^{-1} \mathrm{~s}^{-1}$ ) was $0.4 \%$ per day, notably lower than rates along the flight track (Fig. 1B). This difference illustrates the importance of assimilating aircraft observations in a tracer model to account for distortion of the polar vortex from axial symmetry $(2,3)$. Ozone loss rates found here are similar to those inferred from 
measurements of $\mathrm{ClO}$ in the Arctic lower stratosphere made between 1 and 13 January 1992 by the Microwave Limb Sounder on the Upper Atmosphere Research Satellite (25).

After 1 February, minimum temperatures in the vortex exceeded the threshold for PSCs $(5,9)$, ending PSC processing. Little or no denitrification was observed (26), and $\mathrm{Cl}^{*}$ and rates for ozone destruction began to decline (Fig. 5). The influence of illumination is evident in Fig. 5B: Loss rates were larger for given $\mathrm{Cl}^{*}$ at lower latitudes (lower PV). However, elevated $\mathrm{Cl}^{*}$ persisted longer at high latitudes, and $\mathrm{O}_{3}$ losses integrated over the winter were similar for a wide range of latitudes. About 0.7 part per million by volume (ppmv) (1 ppmy $=10^{-6}$ mole fraction in air) of $O_{3}$

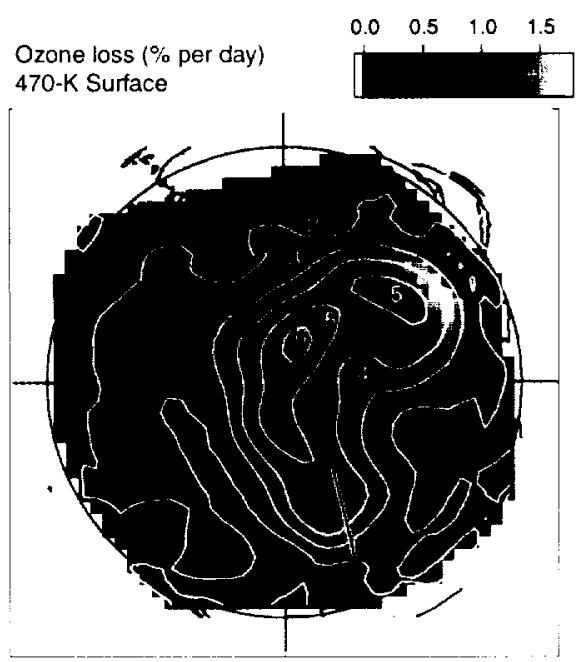

Fig. 4. Distribution of the 24-hour mean loss rate for $\mathrm{O}_{3}$ (percent per day) in the north polar vortex for the $470 \pm 10 \mathrm{~K}$ isentrope, derived with global fields of PV and the relation between $\mathrm{Cl}^{*}$ and PV shown in Fig. 3, as described in the text. Contours of PV (in units of $10^{5} \mathrm{~K} \mathrm{~m}^{2} \mathrm{~kg}$ $s^{1}$ ) and the flight track of the ER-2 (black line. with circle denoting Bangor, Maine) are shown. Latitude circles $60^{\circ}$ and $30^{\circ} \mathrm{N}$ and a map of the continents are denoted by green lines.

Table 1. Photochemical model results for ozone loss at $18 \mathrm{~km}$.

\begin{tabular}{|c|c|c|}
\hline Case & Model conditions & $\begin{array}{c}\mathrm{O}_{3} \\
\underset{(\%)}{\text { removal* }}\end{array}$ \\
\hline A & $\begin{array}{l}\text { PSCs every } 8 \text { days until } \\
25 \text { January }\end{array}$ & 19 \\
\hline B & $\begin{array}{l}\text { PSCs every } 8 \text { days until } \\
26 \text { February }\end{array}$ & 26 \\
\hline C & $\begin{array}{l}\text { Case A plus } 90 \% \\
\text { denitrification at first } \\
\text { PSC event }\end{array}$ & 44 \\
\hline $\mathrm{D}$ & $\begin{array}{l}\text { Case } A \text { plus twice the } \\
\text { present } \mathrm{Cl}_{y}\end{array}$ & 48 \\
\hline
\end{tabular}

"Stated relative to a model without PSCs (see Fig. 6) $(\sim 15$ to $20 \%)$ was removed by reactions 1 through 3 at $\Theta=470 \pm 10 \mathrm{~K}$ in the Arctic polar vortex in 1991-1992, similar to losses for $1988-1989(3,27)$.

The ozone loss rates in Fig. 5B represent snapshots of an isentropic surface on which air parcels move adiabatically (28). Nonadiabatic processes, such as radiative cooling, can significantly modify $\mathrm{PV}$ and $\Theta$ over time scales of a month, with changes in $\Theta$ of about $-70 \mathrm{~K}$ over the winter (29). The seasonal integral at $\Theta=470 \mathrm{~K}$ nevertheless may approximate net ozone removal at $\sim 18$ $\mathrm{km}$ because $\mathrm{O}_{3}$ loss rates are uniform in both vertical $(420<\Theta<500 \mathrm{~K}$ ) (Fig. 2) and horizontal (Fig. 5B) dimensions. Transport of $\mathrm{O}_{3}$ to $\Theta=470 \mathrm{~K}$ during the winter makes it difficult to detect net chemical removal of 0.7 ppmv (8). Analysis of temporal variations of $\mathrm{N}_{2} \mathrm{O}$ and $\mathrm{O}_{3}$ suggest reduction of 15 to $20 \%$ of $\mathrm{O}_{3}$ at $17 \mathrm{~km}(8)$ and 10 to $15 \%$ between 10 and $12 \mathrm{~km}$ (30), consistent with chemical loss rates computed here.

Season-long observations during AASE II provide a unique opportunity to test ideas about the photochemical processes regulating radical concentrations in the polar vortex. We calculated production and loss of $\mathrm{O}_{3}$ and the evolution of $\mathrm{ClO}, \mathrm{HCl}, \mathrm{NO}$, and $\mathrm{BrO}$ from 15 December 1991 to 30 March 1992 for a hypothetical air parcel at $\Theta=470$ $\mathrm{K}, 65^{\circ} \mathrm{N}\left(\mathrm{PV} \approx 2.8 \times 10^{-5} \mathrm{~K} \mathrm{~m}^{2} \mathrm{~kg}^{-1} \mathrm{~s}^{-1}\right)$, assumed to circulate around the vortex every 8 days, by solving time-dependent equations (31) with a comprehensive set of chemical reactants, reaction rates, and photolysis cross sections (20). Data from the ER-2 in December were adopted to define initial concentrations of total nitrogen oxides

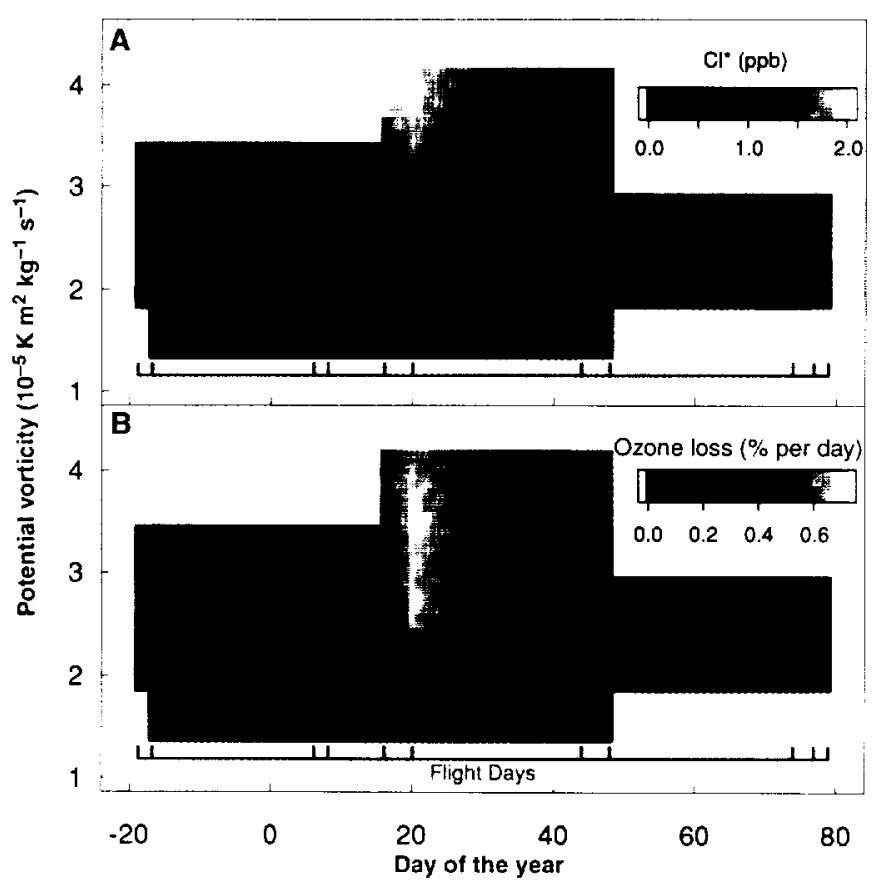

SCIENCE - VOL. $261 \cdot 27$ AUGUST 1993
$\left(\mathrm{NO}_{4}\right)(6), \mathrm{HCl}(7), \mathrm{O}_{3}(8), \mathrm{H}_{2} \mathrm{O}, \mathrm{CH}_{4}$, temperature (9), and the surface area of sulfate aerosols (10) on 15 December. Values of $\mathrm{Cl}_{y}$ were inferred from measured $\mathrm{N}_{2} \mathrm{O}$ $(23,26)$. The reaction efficiency for hydrolysis of $\mathrm{N}_{2} \mathrm{O}_{5}$ on surfaces of sulfate aerosols was assumed to be $0.10(32)$.

Mean temperatures within the vortex $(-210 \mathrm{~K}$ in January, $-230 \mathrm{~K}$ in March) were adopted from meteorological analyses for 1991-1992 (9). Temperatures below the PSC threshold were assumed to occur 1 day out of 8 , from 9 to 25 January (9). Production of $\mathrm{Cl}^{*}$ by reaction of $\mathrm{HCl}$ and $\mathrm{CINO}_{3}$ on PSC surfaces was assumed to be rapid and stoichiometric $(5,7)$. Complete return of $\mathrm{HNO}_{3}$ to the gas phase was assumed upon PSC evaporation, consistent with observations for 1991-92 (26)

Calculated changes of $\mathrm{ClO}, \mathrm{HCl}$ and NO (Table 1, case A) correspond closely to observations (Fig. 6), indicating accurate simulation of rates for key processes regulating $\mathrm{ClO}$ after the cessation of PSCs: photochemical decomposition of $\mathrm{HNO}_{3}$, which regenerates $\mathrm{CINO}_{3}$, and reaction of $\mathrm{Cl}$ with $\mathrm{CH}_{4}$, which regenerates $\mathrm{HCl}$. A study that included detailed air parcel trajectories to examine recovery from PSC processing reached similar conclusions (33). The integrated removal of $\mathrm{O}_{3}$ was $-19 \%$, similar to empirical values from the ER-2 data discussed above.

What conditions would allow high concentrations of $\mathrm{Cl}^{*}$ to persist into spring, as observed in the Antarctic (34)? If PSC processing persisted for another month, $\mathrm{O}_{3}$ losses would increase modestly (Table 1 , case B): Photolysis of $\mathrm{HNO}_{3}$ accelerates rapidly as the season progresses, limiting
Fig. 5. (A) Calculated mixing ratio of $\mathrm{Cl}^{\star}(41)$ and (B) 24-hour mean loss rate for ozone on the $\Theta=470 \pm 10 \mathrm{~K}$ isentropic surface, plotted as a function of PV and day of the year for the Arctic polar vortex in 1991-1992. Day 1 is 1 January 1992, and negative numbers refer to 1991 
loss of $\mathrm{O}_{3}$ after each PSC encounter. Extremely cold temperatures throughout the vortex $(<195 \mathrm{~K})$ in March could produce larger losses of $\mathrm{O}_{3}$ if $\mathrm{HNO}_{3}$ were sequestered in an aerosol phase. If $\mathrm{HNO}_{3}$ were irreversibly removed by the sedimentation of PSCs (denitrification), $\mathrm{Cl}^{*}$ would remain elevated until equinox, and $\mathrm{O}_{3}$ losses would increase significantly $(31,35)$ (Fig. 6 and Table 1, case C). Much of the Antarctic polar vortex is denitrified because of pervasively cold temperatures (36), but only sporadic denitrification has been observed in the Arctic $(26,36)$. Large-scale denitrification could occur in the Arctic if there were an anomalously cold winter or if ice cloud formation were enhanced by increased concentrations of stratospheric $\mathrm{H}_{2} \mathrm{O}$. Cooling of the polar vortex could occur as a result of increasing $\mathrm{CO}_{2}$ (37) or

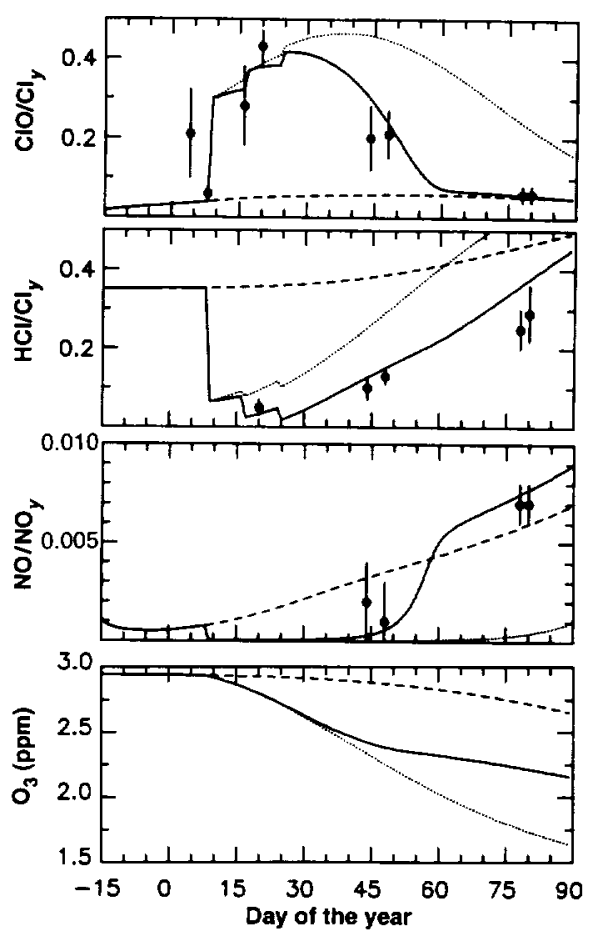

Fig. 6. Calculated seasonal evolution (day 1 corresponds to 1 January) of $\mathrm{ClO}, \mathrm{HCl}, \mathrm{NO}$, and $\mathrm{O}_{3}$ at noon for a hypothetical air parcel circulating at $18 \mathrm{~km}$ altitude, $65^{\circ} \mathrm{N}$ latitude, processed periodically by PSCs as described in the text. Model results for case A in Table 1 (no denitrification), case C $(90 \%$ denitrification following the first PSC event), and a parcel with no PSC processing are shown by the solid, dotted. and dashed lines, respectively. Reductions in $\mathrm{O}_{3}$ during March in the absence of PSC processing occurs because of reactions involving NO . Data points represent mean and standard deviation of observations for $\Theta=470 \pm 30 \mathrm{~K}$ and $P V>2.8 \times 10^{-5} \mathrm{~K} \mathrm{~m}^{2} \mathrm{~kg}^{-1} \mathrm{~s}^{-1}$. Data for $\mathrm{ClO}$ and $\mathrm{NO}$ were restricted to daytime measurements (solar zenith angle $<86^{\circ}$ ). Concentrations of $\mathrm{ClO}, \mathrm{HCl}$, and $\mathrm{NO}$ have been normalized to either $\mathrm{Cl}_{y}$ or $\mathrm{NO}_{y}$ to remove the influence of small-scale atmospheric gradients. declining concentrations of $\mathrm{O}_{3}$ (38). Large ozone reductions would also be expected in the Arctic without denitrification if concentrations of inorganic chlorine were to double beyond present-day values (Table 1 , case D). This scenario appears unlikely if present revisions (39) to the Montreal Protocol of 1987 (40) are effective in reducing inputs of chlorocarbons and bromocarbons to the atmosphere.

\section{REFERENCES AND NOTES}

1. Potential temperature, $\Theta$, is the temperature that an air parcel would reach if it were compressed adiabatically to 1000 mbar. Potential vorticity. PV is a measure of the ratio of the absolute vorticity of a fluid layer to its depth [B. J. Hoskins M E Mclntyre, A W. Robertson, $Q$ J. R. Meteorol Soc 111,877 (1985)]. For the polar stratosphere, $A$ and $P V$ are conserved typically over time scales of several weeks.

2. M. R. Schoeberl et al, J. Geophys. Res. 94, 16815 (1989)

3. R. J. Salawitch et at., Geophys. Res. Lett 17,561 (1990)

4. A vortex circulation forms in the stratosphere over each pole in winter. Air cools radiatively and descends within the vortex, creating steep gradients for tracers across the vortex boundary ( $M$ Loewenstein, J R. Podolske, K. R. Chan, S. E Strahan. Geophys. Res Lett 17, 477 (1990) Temperatures below the threshold for the formation of polar stratospheric clouds are pervasive in the Antarctic vortex and more localized in the Arctic (11).

5. D. W. Toohey ef al., Science 261, 1134 (1993)

6. D. W. Fahey et al, Nature 363, 509 (1993)

7. C. R. Webster ef al, Science 261, 1130 (1993)

8. M. H. Proffitt et al. ibid. p. $\uparrow 150$.

9. P. A. Newman et al, ibid., p. 1143

10. J. C. Wilson et al., ibid. p. 1140

11. M P. McCormick, H M Steele P Hamill, W P Chu, T. J. Swissler, J. Atmos. Sci. 39, 1387 (1982) H. M. Steele, P. Hamill, M. P. McCormick, T. J Swissler, ibid. 40, 2055 (1983)

12. O B Toon P Hamill R P Turco, J Pinto, Geophys. Res. Lett. 13. 1284 (1986): P J. Crutzen and F. Arnold, Nature 324, 651 (1986); D. R Hanson and K. Maversberger, Geophys. Res. Lett 15855 (1988): D R Worsnop L E Fox M S. Zahniser, S. C. Wofsy, Science 259, 71 (1993).

13. M. B. McElroy, R. J. Salawitch, S. C Wofsy, J. A Logan, Nature 321, 759 (1986)

14. S. Solomon, R. R. Garcia, F. S Rowland, D J Wuebbles, ibid., p. 755: W. H. Brune, D. W. Toohey, J. G. Anderson, K. R. Chan, Geophys Res. Lett. 17, 505 (1990)

15. L. T. Molina and M. J. Molina, J. Phys. Chem. 91 433 (1987)

16. K.-K. Tung, M. K. W. Ko, J. M. Rodriguez, N. D Sze Nature 322,811 (1986)

17. R. D. Cadie, P. Crutzen. D. Ehhalt, J. Geophys. Res. 80, 3381 (1975); S. C. Wolsy, ibid. 83, 364 (1978) J F. Noxon, ibid 84, 5067 (1979) W W J Evans, C. T. McElroy, I. E Galbally, Geophys Res. Lett. 12, 825 (1985)

18. D. W. Faney, S. R. Kawa, K. R. Chan, Geophys. Res. Lett. 17, 489 (1990)

19. G. C. Toon et al. J. Geophys. Res. 97, 7963 (1992).

20. W. B. DeMore et al. "Chemical kinetics and photochemical data for use in stratospheric modeling." JPL Publication 92-20 (Jet Propulsion Laboratory, Pasadena, CA, 1992)

21. D. W. Toohey, J. G. Anderson, W. H. Brune, K. R Chan, Geophys Res. Lett. 17, 513 (1990) J. G. Anderson, D. W. Toohey, W. H. Brune, Science 251, 39 (1991).

22. Concentrations of $\mathrm{BrO}$ versus $\Theta$ from 1989 (21) were increased by $-10 \%$ to reflect preliminary data from 1991-1992. The relationship between $\mathrm{Br} r^{*}$ and $\omega$ was developed with use of Eq. 6 and profiles of $\mathrm{Cl}^{*}, \mathrm{O}_{3}$ and temperature inside the vortex for 20 January 1992. A value of $\mathrm{Br}^{*}=12$ parts per trillion by volume (pptv) ( $1 \mathrm{pplv}=10^{-12}$ mole fraction in air) was used for $\Theta=470 \mathrm{~K}$ yielding $\mathrm{BrO}=8.75$ pptv for solar zenith angle $=$ $86^{\circ}$ on 20 January

23. Total inorganic chlorine $\left(\mathrm{Cl}_{4}\right)$ was calculated with the relations between $\mathrm{N} O$ and the source gases $\mathrm{CCl}_{3} \mathrm{~F}, \mathrm{C}_{2} \mathrm{Cl}_{2} \mathrm{~F}_{3}, \mathrm{CCl}_{2} \mathrm{~F}_{2}, \mathrm{CH}_{3} \mathrm{Cl}, \mathrm{CH}_{3} \mathrm{CCl}_{3}$, and $\mathrm{CCl}_{4}$ [J. W. Elkins et al., Eos 73, 106 (1992)], as described by $S$. R. Kawa et al. [J. Geophys. Res. 97, 7905 (1992)]

24. We adopted cross sections from J. B. Burkholder, J. J. Orlando, and C. J. Howard [J. Phys Chem. 94. $687(1990)]$, which gave $\mathrm{Cl}^{*} / \mathrm{Cl} \approx 0.75$ deep inside the vortex. The use of cross sections from (20) [including absorption at longer wavelengths reported by $W$. B. DeMore and $E$. TschuikowRoux (ibid., $\mathrm{P}$. 5856)] gives $\mathrm{Cl}^{*} / \mathrm{Cl}=1$ inside the vortex. Uncertainties in $\mathrm{Cl}^{*}$ have little effect on computed loss rates of $\mathrm{O}_{3}$ because recombination depends mainly on observed daytime concentrations of $\mathrm{CIO}$ ( $\mathrm{Eq} .4$ )

25. J. W. Waters et at. Nature 362,59 ? (1993)

26. M. Loewenstein et al. in preparation.

27. M R Schoeberl et al Geophys Res Lett 17 469 (1990); M. H. Proffitt et al, Nature 347, 31 (1990), D. S. Mckenna el at., Geophys. Res. Lett. 17. 553 (1990): I. S. A. Isaksen, B. Rognerud, F Stordal, M. T Coffey, W. G. Mankin ibid, p 557

28. The $\theta=470 \pm 10 \mathrm{~K}$ surface was chosen for analysis because it was sampled repeatedly over the winter. Surfaces characterized by higher $\theta$ were not sampled until significant warming had occurred (February and March) surfaces with lower $\Theta$ were sampled sporadically during dives

29. J. E. Rosenfield et al. Geophys. Res Lett. 17, 345 (1990)

30. J. Collins and A Weinheimer, personal communication

31. R. J. Salawitch, S. C. Wotsy, M. B. McElroy, Geophys. Res. Lett 15, 871 (1988)

32. M. Mozurkewich and J. G. Calvert. J. Geophys Res. 93, 15889 (1988): J. M. Van Doren et ai Phys. Chem. 95, 1684 (1991): D. R. Hanson and A. R. Ravishankara, J. Geophys. Res 96, 17307 (1991)

33. M. R. Schoeberl et al. in preparation

34. P. M. Solomon et al. Nature 328, $41 \uparrow(1987), W$ H. Brune, J. G. Anderson, K. R. Chan, J Geophys. Res 94,16649 (1989)

35. W. H. Brune et al., Science 252, 1260 (1991).

36. D. W. Fahey et al, Nature 344, 321 (1990)

37. Intergovernmental Panel on Climate Change, Climate Change: The IPCC Scientific Assessment, J. T. Houghton, G. J. Jenkins. J. J. Ephraums, Eds. (Cambridge Univ. Press, Cambridge, 1990), chap. 5

38. "Scientific assessment of ozone depletion 1991 World Meteorological Organization Rep. No. 25 (1991), chap. 7 .

39 Montreal Protocol on the Substances that Deplete the Ozone Layer as Adjusted and Amended by the 4 th Meeting of the Parties, Copenhagen, Denmark. 19 to 21 November 1992. United Nations Environment Program

40. M. B. McElroy and R. J. Salawitch, Science 243 763 (1989)

41. The apparently detached parcel with high $\mathrm{Cl}^{*}$ in early January $\left(21 \times 10^{-5}<\mathrm{PV}<27 \times 10^{-5} \mathrm{Km}^{2}\right.$ $\mathrm{kg}^{-1} \mathrm{~s}^{-1}$ ) is an antifact; small-scale features with high $\mathrm{ClO}$ and low $\mathrm{N}_{2} \mathrm{O}$, characteristic of air with high $P V$ from deep inside the vortex, alternated with low-CIO, high- $\mathrm{N}_{2} \mathrm{O}$ air over 10 - to $100-\mathrm{km}$ scates Meteorological fields of potential vorticity are typically unable to resolve features on this scale (2).

42. Supported by grants from the National Aeronau fics and Space Administration's High-Speed Re search Program and Upper Atmosphere Program and by the National Science Foundation's Atmospheric Chemistry Program Helpful discussions with S. R. Kawa and A. Weaver are gratefuily acknowledged. We thank $L$. M. Avallone and $D$. W. Toohey for helpful discussions and for making data on $\mathrm{ClO}$ and $\mathrm{BrO}$ available.

26 February 1993 accepted 13 July 1993 
